\title{
A crise e o ajuste fiscal no Rio Grande do Sul
}

Sabino da Silva Porto Jr.*

RESUMO - Esse breve artigo comenta as estratégias distintas de combate à crise, adotadas pelo Estado do Rio Grande do Sul e pelo Governo Federal. E defende que o ajuste fiscal com retomada de investimentos é uma política anticíclica mais eficaz do que o aumento dos gastos permanentes praticados pelo governo federal.

Palavras-chave: Ajuste fiscal. Crise. Gastos com pessoal.

Empresas vão sofrer uma acentuada queda nas suas receitas, negócios vão ser interrompidos, o volume das vendas sofrerá uma redução drástica. O impacto social desses fatos é imediato: queda do emprego e da renda, atingindo principalmente as famílias de mais baixa renda. Nessas circunstâncias, o que você faria? Essa é a lógica dos desdobramentos da crise e que tem um impacto direto na sociedade e na contabilidade empresarial. Nessas condições, do ponto de vista das empresas, seria melhor segurar despesas, arrumar a casa, aumentar a eficiência e cortar gorduras.

O setor público segue uma lógica um pouco distinta, afinal, Estados não entram, supostamente, em falência total, empresas ao contrário, se não honram seus compromissos, podem ir a bancarrota, essa é a sua lógica. Contudo, essas diferenças são menos reais do que imaginamos. Ao endividarem-se os governos acabam comprometendo gerações futuras, pois o financiamento da dívida será feito através de novos impostos, pressão inflacionária, aumento de juros ou uma combinação desses três fenômenos. Ao promover gastos incompatíveis com as receitas os estados acabam por cobrar a conta da sociedade como um todo e da iniciativa privada em particular o que pode retardar a recuperação do emprego, da renda e das empresas.

Entender esses desdobramentos e seus encadeamentos é fundamental para que compreendamos a grandeza e o alcance do ajuste das contas públicas do Rio Grande do Sul. Ao recuperar, a capacidade de investir sem aumentar o passivo, o Rio Grande adquiriu musculatura para atenuar os efeitos da crise ao ter a possibilidade de realizar investimentos em setores estruturantes e com capacidade de melhorar a infraestrutura produtiva no Estado. Os

* Professor do PPGE/UFRGS. 
números são ilustrativos, em 2007 com um déficit de aproximadamente $\mathrm{R} \$ 2,4$ bilhões o volume de investimentos foi de apenas $\mathrm{R} \$ 11$ milhões, dois anos depois o déficit foi zerado e

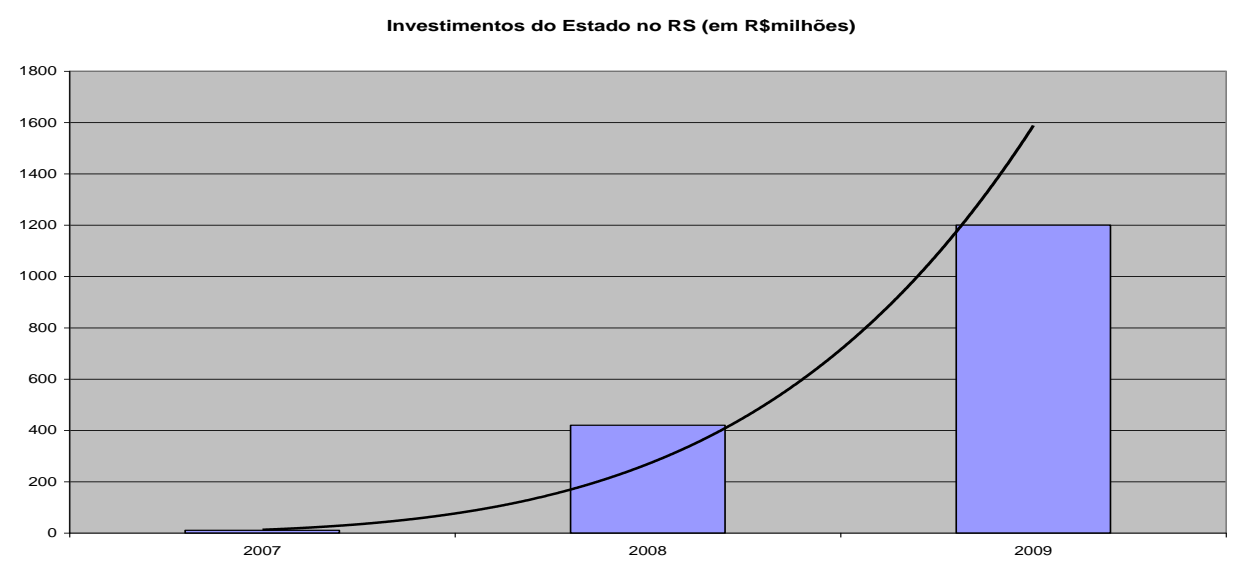

o investimento orçado é de $\mathrm{R} \$ 1,2$ bilhões, sendo que até julho, aproximadamente $60 \%$ já foi executado e/ou licitado. Esses gastos têm função anticíclica e são capazes de estimular a economia através do aumento de produtividade, tornando viável o ambiente de negócios e, por conseqüência, estimulando novos investimentos privados e a recuperação das empresas que mais sofrem com a crise. Esse círculo vicioso, contudo, exige gestão eficiente e visão objetiva das possibilidades de negócios, o que só uma gestão pública moderna e eficiente e a iniciativa privada têm condições de antecipar.

Por outro lado, a estratégia do governo federal caminha na contramão do ajuste fiscal sustentável, pressionada por gastos permanentes que vem crescendo acima da arrecadação a união está perdendo a capacidade de realizar investimentos em áreas vitais e está comprometendo a meta de superávit primário tão importante para uma condução mais tranqüila da política monetária pelo Banco Central.

Arma-se uma bomba relógio que vai comprometer as finanças públicas seriamente, mesmo num cenário, improvável, de crescimento espetacular da economia brasileira nos próximos cinco anos. Uma breve análise dos gastos com a folha de pagamentos revigora esse temor. Em 2008 as despesas com o funcionalismo do Poder Executivo somaram R $\$$ 130,8 bilhões, algo próximo a 4,5\% do PIB. A política de reajustes salariais e de acomodação com o aumento do salário mínimo, já elevou os gastos com servidores em $\$ 11$ bilhões só no primeiro semestre de 2009, o que projeta gastos com pessoal da união para $\mathrm{R} \$ 160$ bilhões o que equivaleria a 5,2\% do PIB, segundo dados do Orçamento da União e Ministério do Planejamento. Sempre é bom lembrar que os gastos com folha de pagamentos ao final de 2002 não chegavam a ultrapassar R $\$ 60$ bilhões. Sendo ainda mais enfático não tenho como 
não citar o Alexandre Schwartzman "Dificilmente poderia ser mais eloqüente: o aumento da despesa corrente corresponde a quase 15 vezes o aumento dos investimentos ( $\mathrm{R} \$ 23,4$ bilhões vs. R\$1,6 bilhão, já ajustados pela inflação)".

Esse cenário, aliado à festejada expansão do crédito dos bancos públicos é uma crônica do passado cujos desdobramentos não deixaram boas lembranças. Ao comemorar o final da crise as autoridades públicas deveriam colocar os parâmetros corretos para uma análise mais sensata, afinal, a que preço está incentivando a economia em setores específicos? Novamente, pegamos o atalho e revigoramos uma visão de expansão dos gastos correntes e com pessoal, negligenciando investimentos de mais longo prazo, (ou alguém acredita na efetividade do PAC?) um estilo bem típico de uma conhecida visão de desenvolvimentismo tão em voga na América Latina. Certamente, o exemplo do Rio Grande tem um fôlego maior no longo prazo e, apesar da crise política enfrentada pelo governo, o ajuste fiscal com retomada de investimentos é uma resposta mais efetiva a crise econômica mundial e sobreviverá como modelo a ser seguido. 
